\title{
Phage DNA synthesis and host DNA degradation in the life cycle of Lactococcus lactis bacteriophage c6A
}

\author{
Ian B. Powell, ${ }^{1}$ Debra L. Tulloch, ${ }^{1}$ Alan J. Hillier ${ }^{2}$ and Barrie E. Davidson ${ }^{1 *}$ \\ ${ }^{1}$ Russell Grimwade School of Biochemistry, University of Melbourne, Parkville, Victoria 3052, Australia \\ ${ }^{2}$ Commonwealth Scientific and Industrial Research Organization, Division of Food Processing, Dairy Research \\ Laboratory, PO Box 20, Highett, Victoria 3190, Australia
}

(Received 29 August 1991; revised 25 October 1991; accepted 28 January 1992)

\begin{abstract}
Bacteriophage c6A is a lytic phage that infects strains of Lactococcus lactis. Infection of $L$. lactis strain $C 6$ resulted in inhibition of culture growth within $10 \mathrm{~min}$, mature intracellular phage particles appeared after $17.5 \mathrm{~min}$, and cell lysis occurred after 25 min. A culture of strain C6 carrying ${ }^{3} \mathrm{H}$-labelled DNA was infected with c6A, and the fate of the radiolabel was monitored. The results showed that degradation of host cell DNA began within 6 min of infection and that the breakdown products were incorporated into progeny c6A DNA. Quantitative DNA hybridizations indicated that synthesis of phage DNA began within 6 min of infection and continued at an approximately constant rate throughout the latent period.
\end{abstract}

\section{Introduction}

Bacterial strains of the genus Lactococcus (formerly known as the mesophilic lactic streptococci; Schleifer $e t$ al., 1985) are used widely in the manufacture of cultured milk products. Infection of lactococcal cultures by lytic bacteriophages is a problem in large-scale dairy fermentations and causes significant production losses. Many lactococcal phages have been isolated and some have been physically characterized. Studies in which phages have been compared by electron microscopy, by electrophoresis of their virion proteins and by DNA hybridization analysis have led to the delineation of several distinct phage types (Jarvis et al., 1991). The same phage types are found in lactococcal dairy fermentations throughout the world.

Current interpretations of lactococcal phage-host interactions are largely based on extrapolation from knowledge of the well-studied archetypal phages of, for example, Escherichia and Bacillus. Although latent periods and burst sizes have been estimated for some lactococcal phages (e.g. Nicholls \& Holloway, 1962; Loof et al., 1983; Powell \& Davidson, 1985), knowledge of their replicative molecular biology remains obscure. Proper understanding of lactococcal phages and informed management of phage-related problems in dairy

* Author for correspondence. Tel. (+61 3) 344 5912; fax (+61 3) 347 7730. fermentations can only come from detailed examination of lactococci and their phages.

Bacteriophage c6A is a lytic phage that infects a range of strains of Lactococcus lactis subsp. lactis. It is typical of the prolate-headed, tailed phages [Stiloviridae (Siphoviridae) morphotype B2] of lactococci (Braun et al., 1989; Powell et al., 1989) and has been chosen as the type phage for this class of bacteriophages (Jarvis et al., 1991). The virion carries linear, double-stranded DNA of $21.9 \mathrm{~kb}$ with cohesive, single-stranded ends. Infection of $L$. lactis subsp. lactis strain $\mathrm{C} 6$ produces a burst of progeny phage particles (about 124 p.f.u. per infected cell) after a latent period of $25 \mathrm{~min}$ (Powell \& Davidson, 1985). In this report we present a study of the replication of phage $c 6 \mathrm{~A}$.

\section{Methods}

General methods. Phage c6A, its host $L$. lactis subsp. lactis (formerly Streptococcus lactis) strain C6, and procedures for the propagation and purification of c6A have been described by Powell \& Davidson (1985). Growth of infected cultures was measured by optical density at $600 \mathrm{~nm}$. Cultures were infected with c6A during exponential growth, at an $\mathrm{OD}_{600}$ of 0.2 to 0.3 (equivalent to 4 to $6 \times 10^{7}$ c.f.u. $\mathrm{ml}^{-1}$ ). Phage multiplicity of infection (m.o.i.) was estimated from input p.f.u. count, c.f.u. count, and the average chain length ( 3.8 cells per chain) of strain C6 (estimated using light microscopy). Phage adsorption to cells was estimated essentially as described by Sanders \& Klaenhammer (1980), and the probabilistic distribution of adsorbed phage particles was estimated using Poisson statistics. 
Growth media. SL1C broth contained $10 \mathrm{~mm}-\mathrm{CaCl}_{2}$, and, per litre, $20 \mathrm{~g}$ tryptone (Oxoid L42), $5 \mathrm{~g}$ yeast extract (Oxoid L21) and $5 \mathrm{~g}$ glucose. SLSD was a semi-defined medium similar to the defined medium of Thompson (1976) but containing $20 \mathrm{~g}$ tryptone $\mathrm{l}^{-1}$ instead of a defined mixture of amino acids. All growth was at $30^{\circ} \mathrm{C}$.

Estimation of eclipse period by premature lysis of infected cells. An exponential-phase culture of $L$. lactis $\mathrm{C} 6$ in SL1C broth was infected with c6A at a m.o.i. of $10^{-4}$ p.f.u. per cell. Samples $(0.2 \mathrm{ml})$ of infected culture were taken at various times and added to $0.8 \mathrm{ml}$ ice-cold $\mathrm{NE}_{10}$ TC [0.25 M-NaCl, $10 \mathrm{~mm}$-EDTA, $10 \mathrm{~mm}$-Tris/HCl (pH 8.0), $0 \cdot 2 \mathrm{mg}$ chloramphenicol (Sigma) $\mathrm{ml}^{-1}$, with $10^{5} \mathrm{U}$ lysozyme (Boehringer Mannheim) $\mathrm{ml}^{-1}$. After $1 \mathrm{~h}$ on ice, infected cells were vortex mixed for $2 \mathrm{~s}$ with chloroform $(20 \%, \mathrm{v} / \mathrm{v}$, final concentration) (Friend $\&$ Slade, 1967), held on ice for $30 \mathrm{~min}$ and then assayed for p.f.u. content.

In vivo labelling of $L$. lactis DNA. Cells from an overnight SL1C broth culture of $L$. lactis $\mathrm{C} 6$ were collected by centrifugation, washed in $2 \%(\mathrm{w} / \mathrm{v})$ tryptone and suspended in one culture volume of SLSD broth. A $2 \mathrm{ml}$ volume of SLSD broth supplemented with [methyl ${ }^{3} \mathrm{H}$ ] thymidine monophosphate $\left({ }^{3} \mathrm{H}\right] \mathrm{TMP}$, Amersham; $\left.2 \mu \mathrm{Ci} \mathrm{ml}^{-1}, 74 \mathrm{kBq} \mathrm{ml}^{-1}\right)$ was inoculated with $20 \mu \mathrm{l}$ washed cell suspension and incubated at $30{ }^{\circ} \mathrm{C}$ for $4 \mathrm{~h}$. Cells carrying ${ }^{3} \mathrm{H}$-labelled DNA were then collected by centrifugation, washed in $2 \%(\mathrm{w} / \mathrm{v})$ tryptone, suspended in $12 \mathrm{ml} \mathrm{SL1C}$ broth and incubated at $30^{\circ} \mathrm{C}$ for $1.5 \mathrm{~h}$ before being used in further experimental procedures.

DNA TCA-precipitation studies. Cells carrying ${ }^{3} \mathrm{H}$-labelled DNA $(0.5 \mathrm{ml}$ samples of broth cultures) were immersed in boiling water for $2 \mathrm{~min}$ in the presence of $1 \%(\mathrm{w} / \mathrm{v})$ sodium dodecyl sulphate (SDS). As described by Maniatis et al. (1982), ice-cold $10 \%$ (w/v) trichloroacetic acid (TCA) and carrier calf thymus DNA were added to the lysates, and TCA-precipitated material was collected by vacuum filtration through Whatman GF/C glass-fibre discs. Discs carrying precipitated material were subjected to scintillation counting.

Density-gradient analysis of phage-induced lysates. A broth culture of cells carrying ${ }^{3} \mathrm{H}$-labelled DNA was infected with c6A (m.o.i. 5 to 10 p.f.u. per cell) and incubated at $30^{\circ} \mathrm{C}$ for $45 \mathrm{~min}$. The culture lysed completely. $\mathrm{CsCl}(6 \mathrm{~g})$ and SLl broth $(3 \mathrm{ml})$ were added to $5 \mathrm{ml}$ of lysate. After ultracentrifugation (Beckman 50Ti fixed-angle rotor, 35000 r.p.m., $48 \mathrm{~h}, 20^{\circ} \mathrm{C}$ ), the contents of the $\mathrm{CsCl}$ gradient tube were collected in $0.47 \mathrm{ml}$ fractions through a puncture in the basal tip of the tube. Material in a pellet at the base of the tube was suspended in $0.9 \mathrm{ml}$ water. This and all gradient fractions were assayed for p.f.u. (by plaque assay) and for scintillation counts per minute (c.p.m.).

Hybridization analysis of phage DNA synthesis. L. lactis C6 was grown in $10 \mathrm{ml}$ SL1C broth. Cells were collected by centrifugation and suspended in $1.5 \mathrm{ml} \mathrm{SL1C}$ broth. Phage c6A ( $10^{10}$ p.f.u.) was added. After $1 \mathrm{~min}$, cells were sedimented (approx. $25^{\circ} \mathrm{C}, 13000 \mathrm{~g}, 30 \mathrm{~s}$ ), suspended in $1 \mathrm{ml} \mathrm{SL1C}$ and sedimented again. The cells were finally suspended in $10 \mathrm{ml} \mathrm{SLIC}$, incubated and sampled at appropriate times. All broth used in these manipulations was pre-warmed to $30^{\circ} \mathrm{C}$. Each sample $(0.5 \mathrm{ml})$ was added to a microtube (Eppendorf 3816$)$ containing $1.5 \mathrm{ml}$ ice-cold $\mathrm{NE}_{100}$ TC [0.25 M-NaCl, 0.1 M-EDTA, $10 \mathrm{mM}$-Tris/HCl (pH 8.0), $0.2 \mathrm{mg}$ chloramphenicol $\mathrm{ml}^{-1}$ ] and held on ice until all samples had been collected. Cells were collected by centrifugation $\left(13000 \mathrm{~g}, 2 \mathrm{~min}, 4^{\circ} \mathrm{C}\right)$ and the pellet was suspended in $50 \mu \mathrm{l} \mathrm{NE} 100 \mathrm{TC}$ with $10^{5} \mathrm{U}$ lysozyme $\mathrm{ml}^{-1}$. After $1 \mathrm{~h}$ on ice, $7 \mu \mathrm{l} \%$ (w/v) SDS and $10 \mu \mathrm{l}$ $2 \mathrm{M}-\mathrm{NaOH}$ were added. Tubes were placed in a $90^{\circ} \mathrm{C}$ water bath for $2 \mathrm{~min}$, and then incubated at $37^{\circ} \mathrm{C}$ for $18 \mathrm{~h}$ to permit alkaline hydrolysis of RNA (Bock, 1967). Alkali-treated samples were neutralized with $67 \mu \mathrm{l}$ of a $1: 1$ mixture of $0.6 \mathrm{M}-\mathrm{HCl}$ and $0.6 \mathrm{M}-\mathrm{NaCl}$, $60 \mathrm{~mm}$-sodium citrate, $1.0 \mathrm{M}$-Tris/ $\mathrm{HCl}(\mathrm{pH} 7 \cdot 4)$. Aliquots $(40 \mu \mathrm{l})$ were applied to nitrocellulose $\left(1 \mathrm{~cm}^{2}\right.$ squares) and baked in vacuo $\left(80^{\circ} \mathrm{C}\right.$, $1.5 \mathrm{~h}$ ). Radiolabelled probes were prepared by the random primer method (Feinberg \& Vogelstein, 1983), using deoxyadenosine $5^{\prime}-[\alpha-$ ${ }^{32}$ P]triphosphate (Bresatec). DNA hybridization conditions were as previously described (Powell et al., 1989) except that $6 \mu \mathrm{g}$ c6A DNA probe was used and $45 \%(w / v)$ formamide was used in hybridization and washing buffers. Hybridized probe was quantified by scintillation counting of filters.

\section{Results}

\section{Growth, infection and lysis of cultures}

Preliminary experiments established conditions for infection of $L$. lactis with phage c6A. A turbidimetric lysis curve of an infection at a m.o.i. of 20 p.f.u. per cell is shown in Fig. $1(a)$. Under these conditions, $93 \%$ of input p.f.u. were adsorbed by cells within $5 \mathrm{~min}$. The distribution of adsorbed p.f.u. can be estimated on the assumption of Poisson variation: less than 1 in $10^{8}$ cells not infected, and virtually all cells multiply infected. Inhibition of culture growth was evident within $10 \mathrm{~min}$ of infection, with almost complete cessation of growth after $15 \mathrm{~min}$. Infection at a m.o.i. of 3 p.f.u. per cell (approx. $7 \%$ of cells not infected, $18 \%$ infected with one phage particle and the remainder infected with multiple particles) resulted in similar but less pronounced inhibition of growth (not shown).

The lysis curve shown in Fig. 1(a) can be compared with the curve shown by Powell \& Davidson (1985) of $L$. lactis $\mathrm{C6}$ infected with c6A at a m.o.i. of 2 p.f.u. per c.f.u., corresponding to about 0.5 p.f.u. per cell of these chain-forming cocci. The latter was a smooth curve, showing only slight inhibition of culture growth prior to

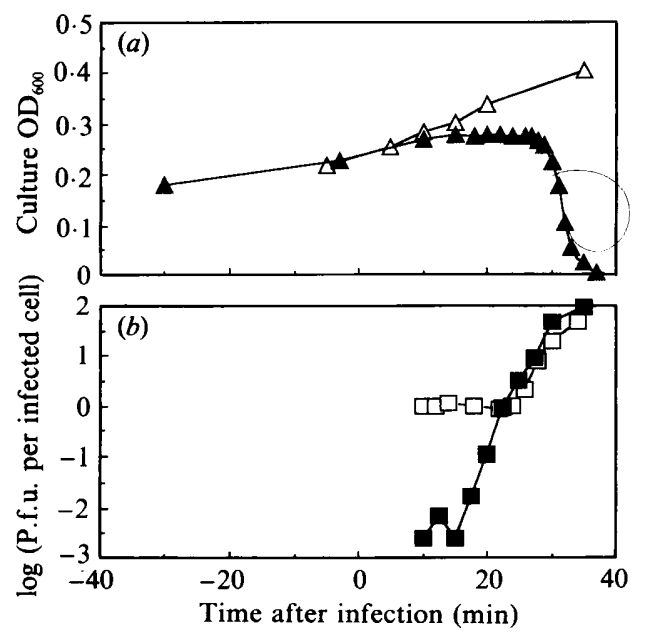

Fig. 1. (a) Turbidimetry $\left(\mathrm{OD}_{600}\right)$ of a culture of $L$. lactis $\mathrm{C6}$ in SL1C broth at $30^{\circ} \mathrm{C}(\triangle)$ and of a parallel culture infected with phage c6 $\mathrm{A}$ at a m.o.i. of 20 p.f.u. per cell $(\Lambda)$. (b) One-step growth (Powell \& Davidson, 1985) of c6A $(\square)$ and release of infective phage from prematurely lysed cells $(\mathbb{\square})$. 
the onset of lysis. The complete lysis of a culture infected at a m.o.i. of less than 1 p.f.u. per cell illustrates that lysis of uninfected cells in the culture can occur due to the action of lytic enzymes released by the lysis of infected cells (Naylor \& Czulak, 1956).

\section{Eclipse period}

Fig. 1(b) shows the results of p.f.u. assays on premature lysates of L. lactis C6 infected with c6A in SL1C broth. Control tests showed that the lysis treatment resulted in cell death (complete loss of c.f.u.) but did not affect the plaque-forming ability of a phage suspension. An increase in p.f.u. $\mathrm{ml}^{-1}$ was detected in samples taken $17.5 \mathrm{~min}$ after infection (with a more pronounced increase by $20 \mathrm{~min}$ ), indicating the presence of fullyassembled phage particles inside the cells at this time, several minutes before the end of the latent period.

\section{Degradation of host cell DNA}

Electrophoretic analysis of nucleic acids isolated from cells grown in the presence of $\left[{ }^{3} \mathrm{H}\right] \mathrm{TMP}$ indicated that the ${ }^{3} \mathrm{H}$ label had been incorporated into DNA and not into RNA, and this was confirmed by the observation that the ${ }^{3} \mathrm{H}$ was in alkali-resistant, TCA-precipitable material (data not shown). L. lactis $\mathrm{C} 6$ carrying ${ }^{3} \mathrm{H}-$ labelled DNA was infected with c6A (m.o.i. 3 to 5 p.f.u. per cell). Samples were taken at various times and lysed by boiling with SDS. Total c.p.m. and TCA-precipitable c.p.m. were determined (Fig. 2). The design of this experiment was such that the total c.p.m. remained constant throughout the infection, and any change in TCA-precipitable c.p.m. would reflect a change in the amount of ${ }^{3} \mathrm{H}$ label which was present in polymeric DNA. A decrease in the TCA-precipitable c.p.m. was clearly evident in samples taken 4 to $6 \mathrm{~min}$ after infection, indicating degradation of the bacterial DNA to a TCA-soluble form. The percentage of c.p.m. which was TCA-soluble continued to increase until 15 to $20 \mathrm{~min}$ after infection, indicating that the rate of host DNA degradation was such that free nucleotides accumulated during this period. This was apparently not the case later in the infection.

\section{Incorporation of host DNA breakdown products into phage DNA}

Fractions were collected from a $\mathrm{CsCl}$ density gradient of a phage-induced lysate of cells carrying ${ }^{3} \mathrm{H}$-labelled DNA (Fig. 3). At least 35\% of the total c.p.m. (in three separate experiments, $35 \%, 41 \%$ and $50 \%$ ) were within the two fractions that contained $85 \%$ of the p.f.u.,

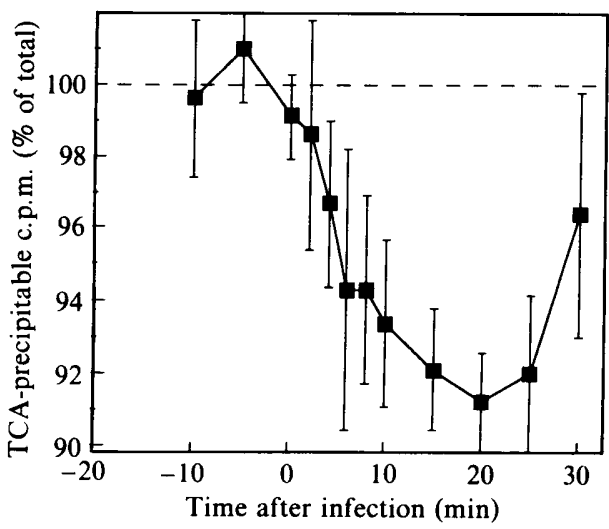

Fig. 2. TCA-precipitation analysis of ${ }^{3} \mathrm{H}$-labelled DNA from c6Ainfected cells carrying ${ }^{3} \mathrm{H}$-labelled DNA. ${ }^{3} \mathrm{H}$ c.p.m. are expressed as percentages of the total c.p.m. (typically 2000 to 5000 c.p.m. per sample) in cell extracts. Data shown are means of four independent experiments, \pm SEM. Cells contained about $10^{-4}{ }^{3} \mathrm{H}$ c.p.m. per cell. In extracts of uninfected cells, an average of $(99.8 \pm 0.8) \%$ of c.p.m. were precipitable with TCA.

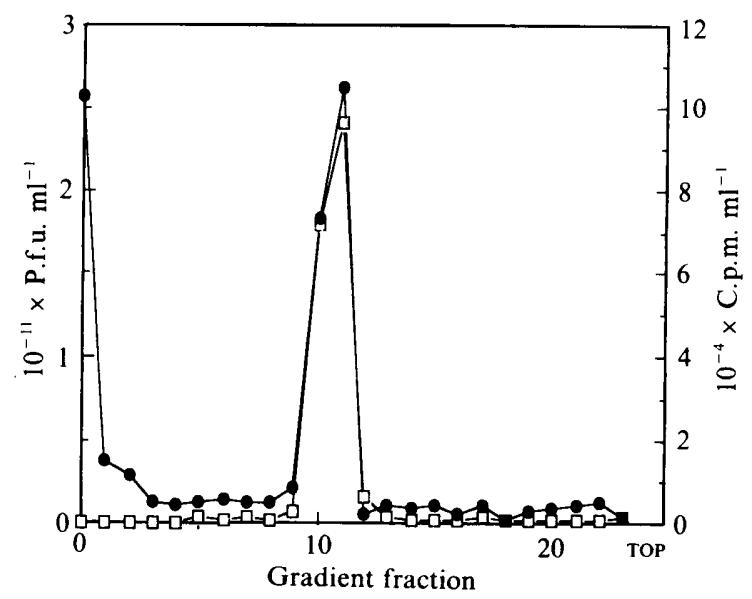

Fig. 3. $\mathrm{CsCl}$ density-gradient analysis of phage-induced lysate. A culture of $L$. lactis $\mathrm{C} 6$ containing ${ }^{3} \mathrm{H}$-labelled DNA was prepared and cells from a $5 \mathrm{ml}$ sample of it were collected for scintillation counting to establish the total c.p.m. in the cells. Another $5 \mathrm{ml}$ sample was infected with $\mathrm{c6A}$ and fractions were collected from a $\mathrm{CsCl}$ density gradient of the lysate. Gradient fractions were assayed for p.f.u. ( $\square$ ) and c.p.m. (O). TOP indicates fractions from the low-density end of the gradient. Fraction 0 contained material from the centrifugation pellet.

indicating that host cell DNA degradation products had been used in the synthesis of phage DNA. Comparable c.p.m. $(45 \%, 28 \%, 24 \%$ of total c.p.m.) were found in a pellet at the bottom of the gradient tube, but no p.f.u. were associated with this material. The nature of this material (virions complexed with sedimented cell debris, incomplete virions, unpackaged phage DNA, or incompletely degraded host cell DNA) was not determined. 


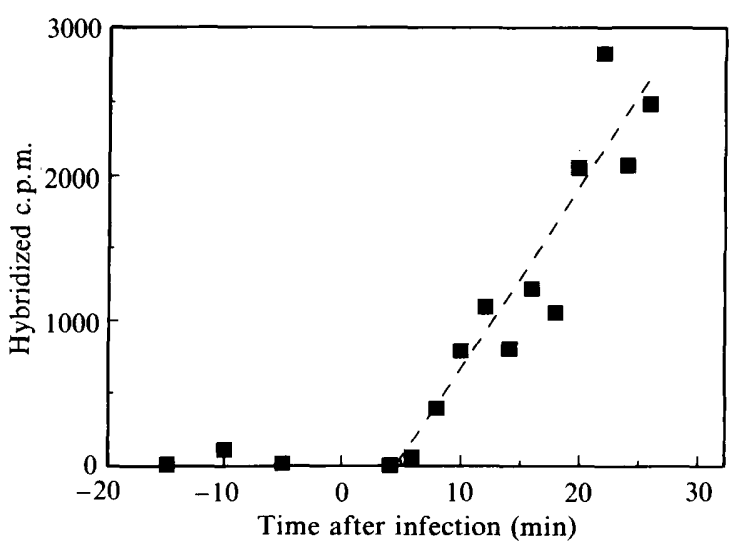

Fig. 4. Quantitative DNA :DNA hybridization analysis of c6A DNA synthesis. DNA in lysates of infected cells was immobilized on nitrocellulose membranes and hybridized with an excess of ${ }^{32} \mathrm{P}$-labelled c6A DNA. Hybridized probe was quantified by scintillation counting. Data shown are means of triplicate filters from a single sample taken at each time point. The calculated regression is shown (broken line).

\section{Synthesis of phage DNA}

Extracts from infected cells were applied to nitrocellulose membranes and probed with ${ }^{32} \mathrm{P}$-labelled c6A DNA to examine phage DNA synthesis (Fig. 4). Control hybridizations indicated that hybridized probe (i.e. c.p.m. bound to the nitrocellulose membranes) was proportional to the amount of c6A DNA applied to the membranes within the range of observed hybridization (corresponding to a range of 0 to $2.5 \mu \mathrm{g}$ c6A DNA applied to each membrane). The infection procedure allowed only a brief exposure of cells to phage (about $20 \%$ of input p.f.u. adsorbed to cells, average of about one phage particle per cell), and ensured that infections were synchronized and that no phage adsorption occurred after the initial exposure. Therefore, increases in phage DNA could be unambiguously attributed to phage DNA synthesis rather than to additional adsorption of phage to cells. No samples were processed prior to $4 \mathrm{~min}$ after infection because of the manipulations required to separate the cells from unadsorbed phage particles.

The most striking feature of Fig. 4 is the linearity of the observed increase in hybridized c.p.m. throughout the latent period, presumably reflecting a constant rate of phage DNA synthesis.

\section{Discussion}

Adsorption of phage c6A to cells and injection of phage DNA occur sufficiently rapidly that breakdown of host DNA and synthesis of phage DNA can be detected within the first few minutes of infection. Phage c6A DNA can be used to transfect $L$. lactis C6 using electroporation (Powell et al., 1988). This indicates that it is not necessary for phage components other than DNA to enter the host cell to lead to productive infection, although the possibility cannot be excluded that such components (e.g. phage products which interfere with host DNA restriction or enzymes which act early after infection) enter the cell during normal infection.

Nyiendo (1975) reported similarity between the DNA base compositions of lactococcal bacteriophages and their host strains. Efficient utilization of the products of host DNA breakdown would be facilitated by such a similarity. The enzymology of degradation of the host DNA is unknown but, whatever nucleases are involved, it is clear that c6A DNA must be immune to these enzymes either because some DNA bases are modified or because the nuclease(s) recognizes base sequences which are not present in phage DNA (Powell \& Davidson, 1986). The size of the L. lactis C6 genome has been estimated to be $2023 \mathrm{~kb}$ (Tanskanen et al., 1990), and would be capable of providing a significant contribution of precursors for phage DNA synthesis.

The result that one-third to one-half of the ${ }^{3} \mathrm{H}$ originally in host DNA could be found associated with mature phage after c6A infection defines a lower limit estimate of the efficiency of packaging of newly synthesized c6A DNA within infected cells. The p.f.u. released in a single cell burst contain about $2700 \mathrm{~kb}$ of DNA (estimated from the observed burst size and the size of c6A DNA). If this represents only one-third to one-half of the total phage DNA synthesized in an infected cell (i.e. not all the phage DNA is packaged into p.f.u.), then the total amount of phage DNA synthesized might be as high as about $8000 \mathrm{~kb}$. Synthesis of this quantity of c6A DNA within the latent period would require production of phage DNA at the rate of 2 to $5 \mathrm{~kb}$ $\mathrm{s}^{-1}$. The rate of polymerization at each c6A DNA replication fork is not known but in Escherichia coli, for example, a replication fork moves at about $1 \mathrm{~kb} \mathrm{~s}^{-1}$ (Kornberg, 1982). Such a rate of synthesis would produce $1500 \mathrm{~kb}$ of DNA in $25 \mathrm{~min}$ at each replication fork, and so it is possible that few c6A DNA replication templates (perhaps only a single parental template) might be required. Synthesis of c6A DNA appears to continue at an approximately constant rate throughout the latent period. The breakdown products of host cell DNA accumulate during the first half of the latent period, indicating that the rate of supply of precursors would not limit the rate of c6A DNA synthesis and suggesting that the constant replication rate results from a constant number of active replication forks.

A regression line $(r=0.94)$ was calculated from the data presented in Fig. 4 and used to estimate the 
approximate time of the start of c6A DNA replication, assuming a constant rate of synthesis. By extrapolating from the calculated regression it was estimated that the hybridized c.p.m. corresponded to the presence of one phage genome per infected cell at 5.4 to $5.7 \mathrm{~min}$ after infection. It can be concluded that c6A DNA synthesis certainly begins less than 6 to $8 \mathrm{~min}$ after infection, probably at 5 to $6 \mathrm{~min}$, and proceeds at an approximately constant rate until cell lysis.

The results of this study provide information on the timing of phage DNA replication, but the precise molecular mechanism remains unknown. Doublestranded DNA phages typically replicate their DNA as polymeric, concatemeric intermediates which are cut into monomers concomitant with packaging of DNA into phage heads (Black, 1989). Hill et al. (1991) have reported preliminary evidence that morphotype B1 lactococcal phage $\phi 31$ replicates via a concatemeric (or possibly circular) intermediate. Newly synthesized monomeric c6A DNA (identified on the basis of incorporation of $\left[{ }^{3} \mathrm{H}\right] \mathrm{TMP}$ into distinctive c6A restriction enzyme digestion fragments) has been detected in crude extracts of infected cells 15 to $18 \mathrm{~min}$ or more after infection (at about the same time as the appearance of intracellular progeny p.f.u.) but not 5 or $10 \mathrm{~min}$ after infection (Powell, 1989). However, it is clear that about one-quarter of all c6A DNA synthesized in infected cells is made within the first $10 \mathrm{~min}$ after infection (Fig. 4), consistent with the suggestion that c6A DNA is synthesized in the form of a large replicative intermediate (possibly membrane-associated; Firshein, 1989) that could not be isolated readily using a crude procedure.

Turbidimetric studies showed that culture growth slows from about $10 \mathrm{~min}$ after infection, perhaps as a result of degradation of cell DNA, although other unknown phage functions might also be involved. The finding that host DNA breakdown begins soon after phage infection has important implications of particular interest to workers involved in the construction of phageresistant lactococcal strains for use in commercial fermentations. Many workers have observed resistance due to abortion of phage infection, reportedly leading to death of the infected cell (Sing \& Klaenhammer, 1990). The molecular mechanisms of infection abortion and cell death are not known. Phage-induced degradation of host DNA could be a cause of cell death in the absence of phage replication.

I. B.P. acknowledges receipt of a Commonwealth Postgraduate Research Award during part of this work. Financial support from the Australian Dairy Research and Development Corporation is gratefully acknowledged. We thank Peter Stewart for helpful suggestions.

\section{References}

BLACK, L. W. (1989). DNA packaging in dsDNA bacteriophages. Annual Review of Microbiology 43, 267-292.

Bock, R. M. (1967). Alkaline hydrolysis of RNA. Methods in Enzymology 12A, 224-228.

Braun, V., Hertwig, S., Neve, H., Geis, A. \& Teuber, M. (1989). Taxonomic differentiation of bacteriophages of Lactococcus lactis by electron microscopy, DNA-DNA hybridization, and protein profiles. Journal of General Microbiology 135, 2551-2560.

Feinberg, A. P. \& Vogelstein, B. (1983). A technique for radiolabeling DNA restriction endonuclease fragments to high specific activity. Analytical Biochemistry 132, 6-13.

FIRSHEIN, W. (1989). Role of the DNA/membrane complex in prokaryotic DNA replication. Annual Review of Microbiology 43, 89120.

Friend, P. L. \& Slade, H. D. (1967). Effect of resistance to chloramphenicol on bacteriophage sensitivity of Group A streptococci. Journal of Virology 1, 50-56.

Hill, C., Massey, I. J. \& Klaenhammer, T. R. (1991). Rapid method to characterize lactococcal bacteriophage genomes. Applied and Environmental Microbiology 57, 283-288.

Jarvis, A. W., Fitzgerald, G. F., Mata, M., Mercenier, A., Neve, H., Powell, I. B., Ronda, C., SaXelin, M. \& Teuber, M. (1991). Species and type phages of lactococcal bacteriophages. Intervirology 32, $2-9$.

KoRnberg, A. (1982). 1982 Supplement to DNA Replication. San Francisco: Freeman.

LOOF, M., LembKe, J. \& Teuber, M. (1983). Characterization of the genome of the Streptococcus lactis "subsp. diacetylactis" bacteriophage P008 wide-spread in German cheese factories. Systematic and Applied Microbiology 4, 413-423.

Maniatis, T., Fritsch, E. F. \& SAMBrooK, J. (1982). Molecular Cloning. A Laboratory Manual. Cold Spring Harbor, NY: Cold Spring Harbor Laboratory.

NAYLOR, J. \& CzULAK, J. (1956). Host-phage relationship of cheese starter organisms. II. Effect of phage activity on heterologous strains of lactic streptococci. Journal of Dairy Research 23, 126-130.

Nicholls, K. D. \& Holloway, B. W. (1962). Latent periods and burst sizes of lactic streptococcal phages. Australian Journal of Dairy Technology 17, 137-139.

NYIENDO, J. A. (1975). Studies on host range, fine structure, and nucleic acids of lactic streptococcus bacteriophages. $\mathrm{PhD}$ thesis, Oregon State University.

POWELL, I. B. (1989). Studies on lytic bacteriophages of lactic streptococci. $\mathrm{PhD}$ thesis, University of Melbourne.

Powell, I. B. \& Davidson, B. E. (1985). Characterization of streptococcal bacteriophage c6A. Journal of General Virology 66, 2737-2741.

Powell, I. B. \& Davidson, B. E. (1986). Resistance to in vitro restriction of DNA from lactic streptococcal bacteriophage c6A. Applied and Environmental Microbiology 51, 1358-1360.

Powell, I. B., ACHen, M. G., Hillier, A. J. \& Davidson, B. E. (1988). A simple and rapid method for genetic transformation of lactic streptococci by electroporation. Applied and Environmental Microbiology 54, 655-660.

Powel. , I. B., Arnold, P. M., Hillier, A. J. \& Davidson, B. E. (1989). Molecular comparison of prolate- and isometric-headed bacteriophages of lactococci. Canadian Journal of Microbiology 35, 860-866.

SANDERS, M. E. \& Klaenhammer, T. R. (1980). Restriction and modification in Group N streptococci: effect of heat on development of modified lytic bacteriophage. Applied and Environmental Microbiology 40, 500-506.

Schleifer, K. H., Kraus, J., Dvorak, C., Kilpper-Balz, R., Collins, M. D. \& Fischer, W. (1985). Transfer of Streptococcus lactis and related streptococci to the genus Lactococcus gen. nov. Systematic and Applied Microbiology 6, 183-195.

Sing, W. D. \& KLAENhammer, T. R. (1990). Plasmid-induced abortive infection in lactococci : a review. Journal of Dairy Science 73, 22392251. 
Tanskanen, E. I., Tulloch, D. L., Hillier, A. J. \& Davidson, B. E. (1990). Pulsed-field gel electrophoresis of Smal digests of lactococcal genomic DNA, a novel method of strain identification. Applied and Environmental Microbiology 56, 3105-3111.
Thompson, J. (1976). Characteristics and energy requirements of an $\alpha-$ aminoisobutyric acid transport system in Streptococcus lactis. Journal of Bacteriology 127, 719-730. 